\title{
Social Network and Healthy Ageing among Elderly in Helping Hearts Old Age Home, Coimbatore
}

\author{
Sangeetha Antony, B.Nalina
}

\begin{abstract}
In the current times, the research cites that elderly definitely need social networks to aid in their mental and physical well being. The previous researches have indicated familyfocused, friend-focused, and restricted types as the types of social networks available. Social network include social interaction and social communication. It is the need of the hour to study about the social network of the elderly population because many of them are left with nobody and loneliness is one of the important factor not to mention about desertion by their loved ones since they are no longer productive individuals. The heterogeneity of social networks is pathway to successful and healthy ageing. Healthy ageing is about using opportunities so that they can have social participation and lead a good quality of life. Elderly need not be burdensome individuals in the society instead they can be involved in lot of activities which contribute to them ageing gracefully. The research studies state that rural elderly have more chances of social participation that they find more meaning in life which is a contributing factor for healthy ageing. The present study aims to find out the relationship between social network and healthy ageing.
\end{abstract}

Index Terms-Elderly, Ageing, Social Network, Healthy Ageing

\section{INTRODUCTION}

A social network is a group of people and group organizations who interact. According to some sociologists" Social networks as the essence of social structure" (Burt 1980) [1]. Healthy Ageing is the focus of WHO's work on ageing between 2015 - 2030. WHO defines Healthy Ageing "as the process of developing and maintaining the functional ability that enables wellbeing in older age" [2]. According to the National Institute on Aging, U.S Department of Health and Human Services, attention is being paid to their diet, increasing the level of activity to health screening to prevent diseases and to manage risk factors so that the elderly can attain healthy ageing [3].

\section{REVIEW OF LITERATURE}

Even the presence of constraints, many rural-dwelling elderly report that positive aspects of rural residence, such as attachment to community, social participation, and familiarity, create a sense of belonging that far outweighs the negative. The review resulted in various articles that highlight the importance of supports to enable elderly to spend time with others; including their pets, volunteering

Revised Manuscript Received on September 14, 2019.

Sangeetha Antony, Assistant Professor, Department of Social Work, Sri Krishna Arts and Science College, (Part time Scholar - Bharathiar University), Coimbatore, Tamilnadu, India.(E-mail: sangeethapaul@skasc.ac.in)

Dr. B.Nalina, Assistant Professor, Department of Social Work, Bharathiar University, Coimbatore, Tamilnadu, India.(E-mail: nalinabathran@gmail.com) and community activities, and help them maintain their home and care for pets [4].

Another study drew the literature on social participation among elderly together to inform the researchers seeking to investigate social participation as an indicator of successful aging. This study points to the fact that enhancing social participation of older adults is a key factor in successful aging that many older adults value. [5].

Yet another study, reveal that engagement was described in terms of personal growth and the pursuit of active engagement, including selection of activities that contributed to individual growth, personal enjoyment and fulfillment, and the improvement of others' well being [6]

Physical function is a significant component of healthrelated quality of life among elderly. Correlation of healthy aging, health behaviors and social network characteristics, were analyzed. Individual health behaviors, defined as current smoking, alcohol consumption, sedentary behavior, and being overweight each contributed to significant reduction in functioning across all age-groups. After controlling for these health behaviors and other variables that influence independent and dependent variable (age, race, education, and co-morbid conditions), elements of a woman's social network were significantly correlated with an individual's ability to do normal daily activities required to meet basic needs and health. The high functioning older women were having close friends and relatives and presence of a confidant. [7].

\section{METHODOLOGY}

The aim of the study is to find the relationship between Social Network and Healthy Ageing among elderly in Helping Hearts Old Age Home, Coimbatore. The objectives were to study the socio demographic profile of the respondents, to find out the level of Social Network and Healthy Ageing, to find out the relationship between Social Network and Healthy Ageing, to find the differences between the socio demographic variables and Social Network and Healthy Ageing and to provide suitable social work recommendations.

The research design used in the study is Descriptive research design to know the relationship between Social Network and Healthy Ageing. The universe of the study includes fifty five elderly in Helping Hearts Old Age Home, Coimbatore. The samples in the study were collected by Census sampling. Researcher selected all fifty five respondents for the study. 
An interview schedule was used for the purpose of data collection and SPSS was used to analyze the data. The researcher used standardized scales for measuring the variables which consisted of three parts. First part consists of personal data of respondents such as age, educational qualification etc. Second part consists of a set of standardized questions which is The Berkman-Syme Social Network Index (SNI) [8]. Third part consists of a set of standardized questions which is the Healthy Aging

Table I shows the Socio-Demographic Variables.

\begin{tabular}{|c|c|c|c|}
\hline $\begin{array}{l}\text { S.No. } \\
\text { I }\end{array}$ & $\begin{array}{l}\text { Socio-Demographic Variables } \\
\text { Age }\end{array}$ & Respondents & Percentage \\
\hline 1 & $60-70$ years & 30 & 54.5 \\
\hline 2 & 71-80 years & 19 & 34.5 \\
\hline \multirow[t]{2}{*}{3} & $81-90$ years & 6 & 10.9 \\
\hline & Total & 55 & 100.0 \\
\hline II & Gender & Respondents & Percentage \\
\hline 1 & Male & 29 & 52.7 \\
\hline \multirow[t]{2}{*}{2} & Female & 26 & 47.3 \\
\hline & Total & 55 & 100.0 \\
\hline III & Educational Qualification & Respondents & Percentage \\
\hline 1 & Illiterate & 28 & 50.9 \\
\hline 2 & Primary & 22 & 40.0 \\
\hline \multirow[t]{2}{*}{3} & High school & 5 & 9.1 \\
\hline & Total & 55 & 100.0 \\
\hline IV & Previous Occupation & Respondents & Percentage \\
\hline 1 & Unemployed & 19 & 34.5 \\
\hline 2 & Odd Jobs & 14 & 25.5 \\
\hline 3 & Semi-Skilled & 11 & 20.0 \\
\hline 4 & Skilled & 8 & 14.5 \\
\hline \multirow[t]{2}{*}{5} & Business & 3 & 5.5 \\
\hline & Total & 55 & 100.0 \\
\hline $\mathbf{V}$ & Previous Income & Respondents & Percentage \\
\hline 1 & unpaid work & 4 & 7.3 \\
\hline 2 & Rs.1000-5000 & 3 & 5.5 \\
\hline 3 & Rs.6000-10,000 & 27 & 49.1 \\
\hline 4 & Rs.11,000-15,000 & 3 & 5.5 \\
\hline 5 & Rs $15,001 \&$ above & 3 & 5.5 \\
\hline \multirow[t]{2}{*}{6} & unemployed & 15 & 27.3 \\
\hline & Total & 55 & 100.0 \\
\hline VI & Religion & Respondents & Percentage \\
\hline 1 & Hindu & 51 & 92.7 \\
\hline 2 & Muslim & 2 & 3.6 \\
\hline \multirow[t]{2}{*}{3} & Christian & 2 & 3.6 \\
\hline & Total & 55 & 100.0 \\
\hline VII & Community & Respondents & Percentage \\
\hline 1 & $\mathrm{BC}$ & 13 & 23.6 \\
\hline 2 & $\mathrm{SC}$ & 34 & 61.8 \\
\hline 3 & MBC & 3 & 5.5 \\
\hline \multirow[t]{2}{*}{4} & SC(A) & 5 & 9.1 \\
\hline & Total & 55 & 100.0 \\
\hline VIII & Marital Status & Respondents & Percentage \\
\hline 1 & Unmarried & 15 & 27.3 \\
\hline 2 & Married & 4 & 7.3 \\
\hline 3 & Separated & 4 & 7.3 \\
\hline 4 & Divorced & 2 & 3.6 \\
\hline
\end{tabular}

Instrument (HAI) by Ladda Thiamwong et al [9] Cronbach's alpha for each of the subscales ranged from .69 80 and the overall HAI was .88 . Network is 0.785 and for Healthy Ageing scale the Cronbach's Alpha Coefficient value is 0.930 .

\section{ANALYSIS AND INTERPRETATION}




\begin{tabular}{|c|c|c|c|}
\hline 5 & Widow & 30 & 54.5 \\
\hline & Total & 55 & 100.0 \\
\hline IX & Occupation of Spouse & Respondents & Percentage \\
\hline 1 & Unemployed & 18 & 32.7 \\
\hline 2 & Odd Jobs & 12 & 21.8 \\
\hline 3 & Semi-Skilled & 3 & 5.5 \\
\hline 4 & Skilled & 4 & 7.3 \\
\hline 5 & Business & 2 & 3.6 \\
\hline \multirow[t]{2}{*}{6} & Not applicable & 16 & 29.1 \\
\hline & Total & 55 & 100.0 \\
\hline $\mathbf{X}$ & No.of children & Respondents & Percentage \\
\hline 1 & 1 & 15 & 27.3 \\
\hline 2 & 2 & 20 & 36.4 \\
\hline 3 & 3 & 2 & 3.6 \\
\hline 4 & $4 \&$ above & 1 & 1.8 \\
\hline \multirow[t]{2}{*}{5} & Nil & 17 & 30.9 \\
\hline & Total & 55 & 100.0 \\
\hline XI & 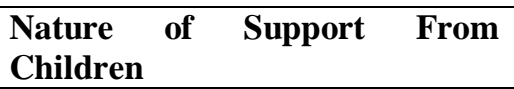 & Respondents & Percentage \\
\hline 1 & None & 23 & 41.8 \\
\hline 2 & Emotional & 21 & 38.2 \\
\hline 3 & Financial & 5 & 9.1 \\
\hline \multirow[t]{2}{*}{4} & no children & 6 & 10.9 \\
\hline & Total & 55 & 100.0 \\
\hline XII & Type of Family & Respondents & Percentage \\
\hline 1 & Nuclear & 39 & 70.9 \\
\hline 2 & Joint family & 2 & 3.6 \\
\hline \multirow[t]{2}{*}{3} & Living alone & 14 & 25.5 \\
\hline & Total & 55 & 100.0 \\
\hline XIII & Area of Residence & Respondents & Percentage \\
\hline 1 & urban & 11 & 20.0 \\
\hline 2 & rural & 25 & 45.5 \\
\hline 3 & semi urban & 11 & 20.0 \\
\hline \multirow[t]{2}{*}{4} & semi rural & 8 & 14.5 \\
\hline & Total & 55 & 100.0 \\
\hline XIV & Hours of Work Per Day & Respondents & Percentage \\
\hline 1 & less than 5 hours & 5 & 9.1 \\
\hline 2 & $5-6$ hours & 7 & 12.7 \\
\hline 3 & $7-8$ hours & 13 & 23.6 \\
\hline 4 & 9-10 hours & 13 & 23.6 \\
\hline 5 & 11-12 hours & 3 & 5.5 \\
\hline \multirow[t]{2}{*}{5} & none & 14 & 25.5 \\
\hline & Total & 55 & 100.0 \\
\hline $\mathbf{X V}$ & Avail Old Age Pension & Respondents & Percentage \\
\hline 1 & Yes & 4 & 7.3 \\
\hline \multirow[t]{2}{*}{2} & No & 51 & 92.7 \\
\hline & Total & 55 & 100.0 \\
\hline XVI & $\begin{array}{l}\begin{array}{l}\text { Years of Availing Old } \\
\text { Pension }\end{array} \\
\end{array}$ & Respondents & Percentage \\
\hline 1 & 1 year & 2 & 3.6 \\
\hline 2 & 2 years & 1 & 1.8 \\
\hline 3 & Above 2 years & 1 & 1.8 \\
\hline \multirow[t]{2}{*}{4} & no old age pension & 51 & 92.7 \\
\hline & Total & 55 & 100.0 \\
\hline
\end{tabular}

Table 1 shows $54.5 \%$ are of the age group $60-70$ years, $52.7 \%$ of respondents are male, half $50.9 \%$ of the elderly are illiterate, $34.5 \%$ of them are unemployed, nearly $49.1 \%$ were earning between Rs. 6000-Rs. 10,000, majority $92.7 \%$ are Hindus, $61.8 \%$ belong to the SC community, $54.5 \%$ of them are widows, nearly $32.7 \%$ of their spouses were

unemployed, around $36.4 \%$ has 2 children, nearly $41.8 \%$ received no support from their children, $70.9 \%$ are from nuclear families, $45.5 \%$ are from rural areas, around $25.5 \%$ 
did not even work a single hour a day, majority $92.7 \%$ did not avail old age pension.

Table 2 shows the Levels of Social Network and Healthy Ageing.

\begin{tabular}{|l|l|r|r|}
\hline S.No. & $\begin{array}{l}\text { Level of } \\
\text { Social } \\
\text { Network }\end{array}$ & Respondents & Percentage \\
\hline 1 & Low level & 28 & 50.9 \\
\hline 2 & Medium & 13 & 23.6 \\
\hline 3 & High Level & 14 & 25.5 \\
\hline S.No. & $\begin{array}{l}\text { Level of } \\
\text { Healthy } \\
\text { Ageing }\end{array}$ & Respondents & Percentage \\
\hline 1 & Low level & 7 & 100.0 \\
\hline 2 & Medium & 42 & 76.4 \\
\hline 3 & High Level & 6 & 10.9 \\
\hline & Total & 55 & 100.0 \\
\hline
\end{tabular}

Table 2 shows the level of social network of elderly is low at $(50.9 \%)$ and the level of healthy ageing of elderly is moderate at $(76.4 \%)$

Table 3 shows Correlation between Social Network and Healthy Ageing.

\begin{tabular}{|l|l|l|}
\hline & $\begin{array}{l}\text { Healthy } \\
\text { Ageing }\end{array}$ & Social Network \\
\hline $\begin{array}{l}\text { Healthy } \\
\text { Ageing }\end{array}$ & 1 & $0.750^{* *}$ \\
\hline $\begin{array}{l}\text { Social } \\
\text { Network }\end{array}$ & $0.750^{* *}$ & 1 \\
\hline
\end{tabular}

Table 3 shows that there is a positive correlation between Social Network and Healthy Ageing that is as Social Network increases Healthy Ageing also increases.

Table 4 shows relationship between Socio Demographic Variable Age with Social Network and Healthy Ageing.

\begin{tabular}{|l|l|l|l|}
\hline & Age & $\begin{array}{l}\text { Healthy } \\
\text { Ageing }\end{array}$ & $\begin{array}{l}\text { Social } \\
\text { Network }\end{array}$ \\
\hline Age & 1 & -0.108 & -0.118 \\
\hline $\begin{array}{l}\text { Healthy } \\
\text { Ageing }\end{array}$ & -0.108 & 1 & $0.750^{* *}$ \\
\hline $\begin{array}{l}\text { Social } \\
\text { Network }\end{array}$ & -0.118 & $0.750 * *$ & 1 \\
\hline
\end{tabular}

Table 4 shows that both Social network (-0.118) and Healthy Ageing (-0.108) is negatively correlated with age which is significant at 0.05 level. It means that as age increases Social Network and Healthy Ageing decreases.
Table 5 shows relationship between Socio

Demographic Variables with Social Network.

\begin{tabular}{|l|l|l|l|}
\hline $\begin{array}{l}\text { S.N } \\
\text { o }\end{array}$ & $\begin{array}{l}\text { Socio- } \\
\text { Demographic } \\
\text { Variables }\end{array}$ & $\begin{array}{l}\text { Social } \\
\text { Network } \\
\text { (F-Value) }\end{array}$ & $\begin{array}{l}\text { Social } \\
\text { Network } \\
\text { Sig. } \\
\text { (P-Value) }\end{array}$ \\
\hline 1 & Gender & 0.709 & 0.665 \\
\hline 2 & $\begin{array}{l}\text { Educational } \\
\text { qualification }\end{array}$ & 1.726 & 0.188 \\
\hline 3 & $\begin{array}{l}\text { Previous } \\
\text { Occupation }\end{array}$ & 1.325 & 0.273 \\
\hline 4 & Previous Income & 2.587 & 0.037 \\
\hline 5 & Religion & 3.188 & 0.032 \\
\hline 6 & Community & 0.764 & 0.519 \\
\hline 7 & Marital Status & 0.924 & 0.458 \\
\hline 8 & No .of children & 0.524 & 0.719 \\
\hline 9 & $\begin{array}{l}\text { Nature of support } \\
\text { from children }\end{array}$ & 2.423 & 0.076 \\
\hline 10 & Type of family & 0.328 & 0.722 \\
\hline 11 & Area of residence & 0.622 & 0.604 \\
\hline
\end{tabular}

The table 5 shows ANOVA between the other socio demographic variables such as gender, educational qualification, previous occupation, previous income, religion, community, marital status, number of children, nature of support from children, type of family and area of residence with Social Network. Since $p$ value is greater than 0.05 there is no significant difference between the socio demographic variables and Social Network. However the previous income $\mathrm{p}$ value is less than 0.05 there is significant difference between previous income and Social Network. Similarly the religion $\mathrm{p}$ value is also less than 0.05 . Hence there is a significant difference between religion and Social Network.

Table 6 shows relationship between Socio

Demographic Variables with Healthy Ageing.

\begin{tabular}{|l|l|l|l|}
\hline $\begin{array}{l}\text { S.N } \\
\text { o }\end{array}$ & $\begin{array}{l}\text { Socio- } \\
\text { Demographic } \\
\text { Variables }\end{array}$ & $\begin{array}{l}\text { Healthy } \\
\text { Ageing } \\
\text { (F-Value) }\end{array}$ & $\begin{array}{l}\text { Healthy } \\
\text { Ageing } \\
\text { Sig. } \\
\text { (P-Value) }\end{array}$ \\
\hline 1 & Gender & 0.792 & 0.727 \\
\hline 2 & $\begin{array}{l}\text { Educational } \\
\text { qualification }\end{array}$ & 0.079 & 0.924 \\
\hline 3 & Occupation & 1.016 & 0.408 \\
\hline 4 & Income & 1.206 & 0.320 \\
\hline 5 & Religion & 3.679 & 0.032 \\
\hline 6 & Community & 0.321 & 0.810 \\
\hline 7 & Marital Status & 0.846 & 0.503 \\
\hline 8 & No .of children & 0.403 & 0.805 \\
\hline 9 & $\begin{array}{l}\text { Nature of } \\
\text { support from } \\
\text { children }\end{array}$ & 1.014 & 0.394 \\
\hline 10 & Type of family & 1.468 & 0.240 \\
\hline 11 & $\begin{array}{l}\text { Area } \\
\text { residence of }\end{array}$ & 0.571 & 0.637 \\
\hline
\end{tabular}


The table 6 shows ANOVA between the other socio demographic variables such as gender, educational qualification, previous occupation, previous income, religion, community, marital status, number of children, nature of support from children, type of family and area of residence with Healthy Ageing. Since p value is greater than 0.05 there is no significant difference between the socio demographic variables and Healthy Ageing. However the religion $\mathrm{p}$ value is also less than 0.05 . Hence there is a significant difference between religion and Healthy Ageing.

\section{MAJOR FINDINGS}

Majority, 92.7\% did not avail old age pension and belong to the Hindu religion. Half of the elderly are between 60-70 years of age, are of male gender, illiterate and widows. $70.9 \%$ are from nuclear families and $61.8 \%$ belong to the SC community. $45.5 \%$ are from rural areas.

The level of social network of elderly is low at (50.9\%) and the level of healthy ageing of elderly is moderate at $(76.4 \%)$.

There is a positive correlation between Social Network and Healthy Ageing. There is a negative correlation between Age and Social Network and Healthy Ageing.

There is significant difference between income and Social Network. There is also a significant difference between religion with Social Network and Healthy Ageing.

\section{DISCUSSIONS}

From the above findings it is evident that the level of Social Network is low at $50.9 \%$. In old age homes the avenue for Social Network is also low. They are restricted to their old age home. They do not have many contacts other than those residing in the old age home. There is also a positive correlation between Social Network and Healthy Ageing. The present study shows that as age increases Social Network as well as Healthy Ageing decreases. Therefore if we are able to increase the Social Network of the elderly their Healthy Ageing would also increase. The elderly population is increasing in our country. They need not be a burden to the society, if we are able to make them age in a healthy manner they will be a productive and contributing member of the society. Hence strategies such as Social Work Interventions which are tailor made should be devised to increase the Social Network of the elderly so that the Healthy Ageing also increases.

\section{SOCIAL WORK INTERVENTIONS}

Social work provides intervention to deal with issues of health and aging. The interventions used by social workers should follow evidence based practice guidelines for effectively assessing and treating elderly and their families.

Social work interventions are selected on the basis of the issues, needs and strength of the elderly.

\section{Social Case Work}

Social case work is a method used by professionally trained social workers in social work agencies or organizations to help people with their problems of social functioning. The practice of case work is helping the elderly to define the goals, needs, aspirations and support them to achieve those. Wherever they are having hindrance in their autonomy the social workers can provide them with alternate options.

\section{Counselling and Guidance}

Counselling refers to a professional advice given by a counsellor to an individual to help him in overcoming from personal or psychological problems. Since the elderly face physical and cognitive limitations as part of the aging process counselors have a major role to play in making the elderly lead a good quality of life. Guidance is to advice or provides information by a superior, to solve a problem. The goals for guidance can be prevention of falls and promotion of physical activity.

\section{Social Group Work}

Social group work is a method of social work that helps persons to enhance their social functioning through purposeful group experiences and to cope more effectively with their personal, group or community problems (Marjorie Murphy, 1959). Group work has played an important role in health promotion and the assessment and treatment of diseases.

\section{Community Organization}

Community organization covers a series of activities at the community level aimed at bringing about desire improvement in the social well-being of individuals, group and neighborhoods. Community programs can be done to improve the social participation of the elderly thereby increasing their healthy ageing.

\section{Social Work Research}

Social work research is the application of research methods to solve the problems that social worker confront in the practice of social work. The study about elderly should be taken up for research more extensively. The findings should be used in framing the policies and developing schemes which are beneficial for the elderly.

\section{RECOMMENDATIONS}

The above Social Work Interventions are very broad. There is a need to develop specific interventions which will increase the Social Network and thereby increase Healthy Ageing for the elderly. Further social work research in this area should be done to increase the Social Network of the elderly. It is the need of the hour to find out suitable specific social work interventions in this area of study so that every elderly in our country can be an asset to the people of this country. Their self esteem can be improved and they will also feel happier as they are also a part in building our nation further up in all aspects in the global arena. Their wealth of experience is resourceful and should be made use of in the development of our great nation.

\section{CONCLUSION}

Research has revealed in this present study that there is positive relationship between Social Network and Healthy

Published By:
Blue Eyes Intelligence Engineering
\& Sciences Publication


Ageing. Efforts should be made by old age homes across the cities to increase the Social Network and thereby increase healthy ageing. Policy makers can make suitable recommendations to the people involved in running old age homes to increase activities that promote the Social Network of elderly. May elderly be a boon and not a bane

\section{REFERENCES}

1. Clifton D. Bryant., Dennis L. Peck \& Donald M. Peck., "Sociology of Social Networks," $21^{\text {st }}$ Century Sociology: A Reference Handbook, Sage Publications, 208,19 Mar. 2011.

2. World Health Organization. (2019). What is Healthy Ageing?. [online] Available at: https://www.who.int/ageing/healthy-ageing/en/ [Accessed 8 Sep. 2019].

3. National Institute on Aging. (2019). What do we know about Healthy Ageing?. [online] Available at: http://www.nia.nih.gov/health/ [Accessed 8 Sep. 2019].

4. Lisa F. Carver., Rob Beamish., Susan P. Phillips \& Michelle Villeneuve., "A Scoping Review: Social Participation as a Cornerstone of Successful Aging in Place among Rural Older Adults," Journal of Geriatrics. 4(3), 75, Dec 2018.

5. Heather, Douglas., Andrew, Georgiou \& Johanna,Westbrook., "Social participation as an indicator of successful aging: an overview of concepts and their associations with health," Australian Health Review.41(4),455-462, Aug 2017.

6. Reichstadt, J., Sengupta ,G., Depp C,A., Palinkas L,A \& Jeste D,V., "Older Adults' Perspectives on Successful Aging: Qualitative Interviews," American Journal of Geriatric Psychiatry.18(7),567-75, July 2010.

7. Yvonne L. Michael., Graham A. Colditz., Eugenie, Coakley \& Ichiro, Kawach., "Health behaviors, social networks, and healthy aging: Cross-sectional evidence from the Nurses' Health Study," Quality Life Research. 8, 711, Dec 1999.

8. Berkman, L.F. \& Syme, S.L., "Social networks, host resistance and mortality: a nine year follow up study of Alameda County residents," American Journal of Epidemiology, 109, 186, 1979.

9. L. Thiamwong., W. Maneesriwongu., P. Malathum., S. Jitapunkul., T. Vorapongsathorn \& A.L. Stewart., "The Healthy Aging Instrument (HAI): Development and Psychometric Evaluation," Innovation in Aging, 1,2017 